\title{
Phytochemical Analysis of Euphorbia Hirta and Cytotoxic Activity on Ma104
}

\author{
Ponnambalam Arun*, Kaveri Krishnasamic, Palani Gunasekeranc and Vidya Padmanabhan \\ Research Scholar, Department of Virology, India \\ *Corresponding author: Ponnambalam Arun, Department of Virology, King Institute of Preventive Medicine \& Research, Guindy, \\ India
}

Received: 漈January 26, 2019

Published: 眥 February 01, 2019

\begin{abstract}
Diarrheal diseases continue to be largest and deadliest ones globally especially affecting children. From earlier days there is renewed interest in the discovery of novel compounds that can be used to fight these kinds of diseases using plants and its materials. Rotavirus has been recognized as the major etiological agent of diarrheal diseases of young children in developed as well as developing countries. The presence of various phytochemicals like flavonoids, tannins, saponins, alkaloids and terpenes present in the active extracts increase the colonic water and electrolyte reabsorption and result in treatment of diarrhea. This study was undertaken to know about traditional herbal plant having medicinal value. Euphorbia hirta was analyzed for the presence of phytochemical and cytotoxic activity using MA104 cell line. Non toxic dose of the extracts were used to determine their in-vitro inhibitory activity. Cytotoxic activity were assessed using (3-(4,5-Dimethylthiazol-2-yl)-2,5-Diphenyltetrazolium Bromide) (MTT). The cytotoxicity from crude acetone extract of Euphorbia hirta had activity in non-toxic concentration. The potency of the plant extract concentration has been calculated using percent decrease in number of viable cells in MA104 compared with control value. This observation of potential activity on MA104 are worth for further studies and present study corroborates ethno pharmacological data as a valuable source in the selection of plants with antiviral activity and to some extent validates their traditional use.
\end{abstract}

Keywords: Phytochemical; Cytotoxicity; Euphorbia hirta; MA104; Antiviral activity

\section{Introduction}

Gastroenteritis is an inflammation of the gastrointestinal tract which involves stomach and intestine. Although gastroenteritis are caused by many pathogens, most of the infections are caused by viruses, in particularly, by rotavirus. It is the most common diarrhea-causing pathogen in children world-wide. Every year two million children are hospitalized, and 800,000 deaths occur due to rotavirus associated diseases [1]. The virus is transmitted through oral-fecal route. Usually clinical symptoms of rotavirus illness due to gastroenteritis ranges from mild, watery diarrhoea which leads to severe diarrhoea associated with vomiting and fever, leading to dehydration with shock, electrolyte imbalance, and death [2]. Rotaviruses are double stranded RNA viruses contains 11 segments in the family of Reoviridae and are the major cause of gastroenteritis in young children and animals, including many mammalian and avian species. Although number of mammalian group of rotaviruses are grown in cultured cells, culturing of human rotavirus was difficult for some time. Successful cultivation of human isolate was done after eleven passages through gnotobiotic piglets [3]. The strain called as WA-11 is being widely grown in primary cell lines and continuous cell types. There are studies demonstrating that human rotavirus can be grown directly in monkey kidney cells without passage through animals. [4,5] VP7 and VP4 are the two major structural proteins in the outer capsid of rotavirus genome. They have independent neutralization antigens and define P (for protease - sensitive) and G (for glycoprotein) types respectively. VP4 is an important determinant of host cell tropism, $[6,7]$ virulence, [8] receptor binding [9] and cell penetration [10].

MA104 cells together with pretreatment of the specimens with trypsin and incorporation of small amount trypsin in maintenance medium aids in the cultivation of human rotaviruses in recent 
times. [4, 5] Trypsin treatment of viruses has shown an increase in virus infectivity as much as 100 -fold and growth in cells up to 10,000 fold [11]. The development of vaccine to prevent rotavirus illness is of highest priority in international and national health with most efforts aiming at the development of cost effective vaccines directed against epidemiologically important serotypes $[12,13]$. The interest to develop and make research in plant derived medicines is basically due to multidrug resistance of antibiotics such as MRSA and recent time widespread of green prescription [14]. Guava leaves are used internally in dysentery and diarrhoea cases [15]. Nowadays many natural compounds have known antirotavirus effects in clinical studies [16-18]. Vaccines to prevent RGE were developed subsequent to recognition that infection by wildtype rotavirus leads to and induces immunity against repeated infections. Since 2006 WHO has recommended the use of two oral vaccines Rotateq and Rotarix and from 2015 Rotavac has been recommended to be included in routine vaccination program. The disadvantages of the current drugs led researchers to try for newer drugs of cheap, safe and effective for use against RGE. In Tamil Nadu, one of the southern states in India, where rotavirus vaccine is not part of the routine immunization schedule during the study period, however, it's being administered by private practitioners nowadays. Medicinal plants consider as source of newer antiviral agents and therefore in the present study we investigated Euphorbhia hirta for in-vitro anti-rotavirus activity by determining the cytotoxic action on MA104 cells by evaluating the number of viable cells after incubation with plant extract at different concentrations. MA104 cells is an established cell line for isolation of rotavirus infection studies in which rotavirus receptors have been identified and reported. Rotaviruses are known to infect the epithelial cells of small intestine in-vitro [19].

\section{Euphorbia Hirta}

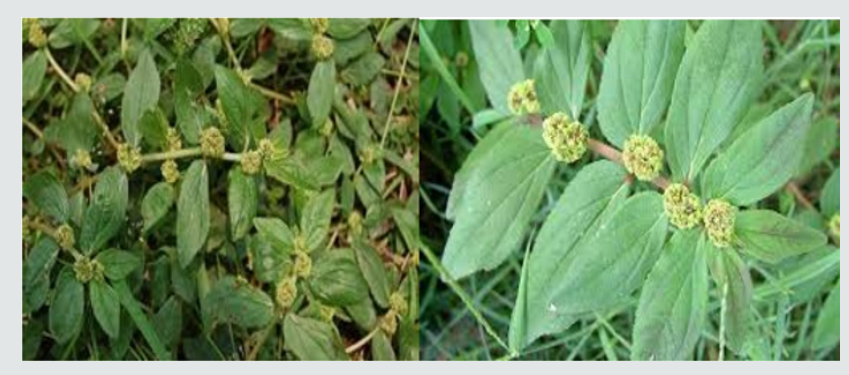

Figure 1: Euphorbia hirta.

Euphorbia hirta is a medicinal plant belonging to genus Euphorbia of the family and Class Magnoliopsida under the Kingdom Plantae [20]. (Figure 1) Famously it is widely used as local and traditional medicine of China (TCM) and the whole plant is applied to cure various diseases especially gastrointestinal disorders (intestinal parasites, dysentery, diarrhea, vomiting, heat burn and peptic ulcers). The plant is native of Central America. It was introduced in to South East Asia a long time ago and since spread throughout. It is common plant of pan tropic and partially subtropics area like India, China, Philippines, and so on. It is a medicinal, rhizomatous herb distributed in Southern Western Ghats of India and north eastern parts of Tamilnadu. EH is used in traditional medicines to treat gastrointestinal disorders, bronchial and other respiratory disease, conjunctivitis, increase milk flow in women and other female related problems. It was also used for intestinal parasites, diarrhoea, peptic ulcers, heartburn, vomiting, amoebic dysentery, asthma, bronchitis, hay fever, laryngeal spasms, emphysema, coughs, colds, kidney stones.

\section{Materials and Methods}

\section{Plant Collection}

Based on the documented ethno pharmacological knowledge on the use of medicinal plants in the treatment of diarrheal diseases, fresh plants of Euphorbia hirta were chosen for this study. During the month of July and August plants were collected from abandoned lands near Kanchipuram.

\section{Preparation of extracts}

Whole plants and its parts were washed two to three times in distilled water and air dried in shadow, and grinded into fine powder using electric grinder. The crude drug was extracted using Acetone. The solution of the extract was filtered through Whatman filter paper no.1 and concentrated using rotary flash evaporator and dried under vacuum. They were labeled separately in brown bottle and stored with proper labeling for further analysis.

\section{Cell Culture}

MA 104 an adherent cell line which is used for isolation of rotavirus from faecal samples, responsible for diarrhoea among children. MA 104 cells has been grown in Dulbecco's Modified Eagle Medium (DMEM) supplemented with $10 \%$ of heat inactivated fetal bovine serum with antibiotics in a humidified $5 \% \mathrm{CO} 2$ at $37^{\circ} \mathrm{C}$. Medium used for test purpose was replaced with 2\% FCS along with $1 \%$ trypsin with the above mentioned antibiotics for assay. MA104 obtained from African Green Monkey fetal kidney has been bought from NCCS Pune.

\section{In-vitro experiments}

\section{Cytotoxicity Assay}

The assay is carried out using (3-(4, 5-dimethyl thiazol-2yl)-2, 5- diphenyl tetrazolium bromide (MTT) [20], MTT is cleaved by mitochondrial succinate dehydrogenase and reductase of viable cells, yielding a measurable purple product formazan.

This formazan production is directly proportional to the viable cell number and inversely proportional to the degree of cytotoxicity $[21,22] . M A 104$ cell was trypsinised, and the cells were suspended in the growth medium containing $10 \%$ FCS by gentle passage with the pipette and then cells were homogenized. $1 \mathrm{ml}$ of the homogenized cell suspension was added to each well of a 96 well 
culture plate and incubated at $37^{\circ} \mathrm{C}$ in a humidified $\mathrm{CO}_{2}$ incubator with $5 \% \mathrm{CO}_{2}$. After $48 \mathrm{hrs}$ incubation the cells were observed under an inverted tissue culture microscope. Then the cells were treated with different concentrations of the extract followed by additional 72 hour incubation at $37^{\circ} \mathrm{C}$. The cells were observed daily to determine the minimum concentration that induced changes in cell morphology. After that the medium was removed from wells and added with $100 \mu \mathrm{l}$ of MTT solution ( $5 \mathrm{mg} / \mathrm{ml}$ ) for $4 \mathrm{hr}$ at $37^{\circ} \mathrm{C}$. MTT solution was removed and $50 \mu \mathrm{l}$ of DMSO was added to remove the formazan crystals followed by incubation for 30 minutes in $\mathrm{CO}_{2}$ incubator. OD value was measured at 540nm in ELISA reader. Data were obtained from triplicate wells.

The $50 \%$ cytotoxic concentration was calculated as

$\mathrm{CC} 50=\mathrm{A}-\mathrm{B} / \mathrm{A} \times 100$, where

$A=$ mean of the OD of untreated cells

$\mathrm{B}=$ mean of the OD of treated cells

\section{Results}

Phytochemical analysis of the plants used for this study revealed presence of various active components in them to be used for treating diarrheal diseases (Table 1). There was no significant difference between the control and the extract treated group in aspect of cell viability on MA104 cells at at $200 \mathrm{mg} / \mathrm{ml}$ and cytotoxicity at non-toxic concentration of $180 \mathrm{mg} / \mathrm{ml}$ was observed in Euphorbia hirta crude extract. This showed that Euphorbia hirta was effective in terms of cytotoxicity.

Table 1: Phytochemical screening of Euphorbia hirta.

\begin{tabular}{|c|c|}
\hline Phytochemicals & Acetone extract \\
\hline Alkaloids & + \\
\hline Flavonoids & + \\
\hline Phenol & + \\
\hline Quinones & + \\
\hline Tannins & - \\
\hline Carbohydrates & + \\
\hline Steroids & + \\
\hline Glycosides & + \\
\hline Trepenoids & - \\
\hline Ninhydrin & - \\
\hline Saponins & \\
\hline
\end{tabular}

\section{Discussion}

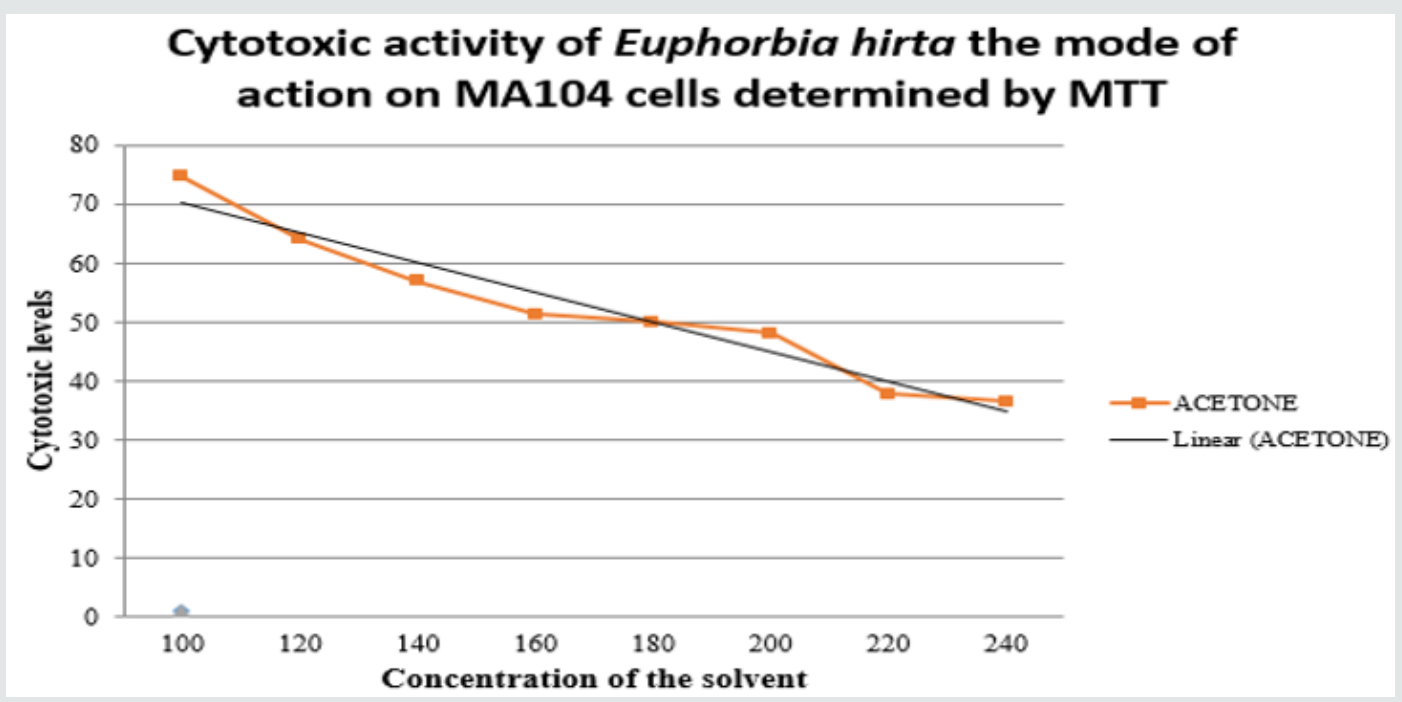

Figure 2: Cytotoxicity activity of Euphorbia hirta acetone extract on MA104 cells.

Rotavirus is found to be reported as most common pathogen of diarrheal diseases worldwide affecting children under five years of age and in spite of vaccines available to this infection for clinical use, however they are specific against certain strains besides of high cost and side effects the use is of restriction. In this present study the acetone extracts of Euphorbia hirta was investigated in-vitro. We used simple staining method (MTT) to identify the cytotoxicity effect of plant extracts used on MA104. Our result showed that higher activity of acetone extract from Euphorbia hirta was seen when pre-incubated with cells prior to infection and when added to cells after incubation by $50 \%$. (Figure 2) The activity of crude extracts may be due to many different compounds such as alkaloids, flavonoids, steroids, tannins, and phenolic compounds [23]. There are various reports of phenol and flavonoids present in the crude extracts, which have antiviral activity against several RNA viruses. Anti-rotaviral activity has been reported by Bae et al. [24], Shaeen et al. [25] and Goncalves et al. [26] Virucidal activity when using Aegle marmelos decotions has been observed by S Brijesh et al. [27] 10\% dilution of the extract. Study by Ha-hyun Kim et al. [28] showed crude extracts of Alpinia katsumadai had anti-rota viral activity from $0.7 \pm 0.4$ to $33.7 \pm 6.5 \mu \mathrm{g} / \mathrm{ml}$. Luciane et al. [29] showed that some flavonols, present which possessed two or more 
methoxyl and ethoxy radicals, one or two butoxyl radicals, and one benzyloxyl radical showed antiviral activity against rotavirus [30]. Presence of flavonoids in our crude extract has been tested and reported. Methanolic extracts of Rinderalanta plant from Turkish showed selective index by focus reduction assay from crude extract exhibited activity from $5.5 \mu \mathrm{g} / \mathrm{ml}$ to $25.5 \mu \mathrm{g} / \mathrm{ml}[29,31]$. which is equal to $400 \mathrm{mg} / \mathrm{ml}$ concentration where in our study we found the concentration to be $200 \mathrm{mg} / \mathrm{ml}$. The above studies shows that the natural plant has anti-diarrheal anti-rotaviral activity in different parts of the country and therefore we conclude that the plant used in this investigation is having cytotoxic activity against the cell line MA104 that is used for isolation of rotavirus, therefore the antiviral activity can be studied further using the plant and their components.

\section{References}

1. Padmanabhan Vidya, Ponnambalam Arun, Palani Gunasekeran, Kavitha Arunagiri, Mohana Sambasivam, Kaveri Krishnasami (2015) Rota virus infections: prevalence, diagnosis and prevention. Journal of Pediatric Sciences 7: e244.

2. Estes MK (1996) Rotaviruses and their replication. In: Fields BN, Knipe DM, Howley P M, Chanock RM, Melnick JL, Monath TP, Roizman B, Straus SE, (Eds.). Fields virology. ( $3^{\text {rd }}$ edn). Philadelphia, Pa: Lippincott-Raven Publishers, pp. 1625-1655.

3. Wyatt RG, James WD, Bohl EH, Theil KW, Saif LH, et al. (1980) Human rotavirus type 2: cultivation in vitro. Science 207(4427): 189-191.

4. Sato K, Inaba Y, Shinozaki T, Fujii R, Matumoto M (1981) Isolation of human rotavirus in cell culture. Arch Virol 69(2): 155-160.

5. Urasawa T, Urasawa S, Taniguchi K (1981) Sequential passages of human rotavirus in MA104 cells. Microbiol Immunol 25(10): 1025-1035.

6. Kalica AR, Flores J, Greenberg HB (1983). Identification of the rotaviral gene that codes for hemagglutination and protease-enhanced plaque formation. Virology 125(1): 194-205.

7. Ramig RF, Galle KL (1990) Rotavirus genome segment 4 determines viral replication phenotype in cultured liver cells (HepG2). Journal of Virology 64(3): 1044-1049.

8. Hoshino Y, Saif LJ, Kang SY, Sereno MM, Chen WK, et al. (1995) Identification of group A rotavirus genes associated with virulence of a porcine rotavirus and host range restriction of a human rotavirus in the gnotobiotic piglet model. Virology 209(1): 274-280.

9. Kirkwood CD1, Bishop RF, Coulson BS (1998) Attachment and growth of human rotaviruses RV-3 and S12\}85 in Caco-2 cells depend on VP4. J Virol 72(11): 9348-9352.

10. Ludert JE, Feng N, Yu JH, Broome RL, Hoshino Y (1996) Genetic mapping indicates that VP4 is the rotavirus cell attachment protein in vitro and in vivo. Journal of Virology 70(1): 487-493.

11. Clark SM, Roth JR, Clark ML, Barnett BB, Spendlove RS (1981) Trypsin Enhancement of Rotavirus infectivity: Mechanism of Enhancement. Journal of Virology Sept 39(3): 816-822.

12. Bishop RF (1993) Development of candidate rotavirus vaccines. Vaccine 11(2): 247-254.

13. Ellis RW (1992) Vaccines: New Approches to Immunological Problems. Butterworth-Heinemann Press, Boston, pp. 255-288.

14. Jigna P, Sumitra C (2006) In-vitro antimicrobial activities of extracts of LaunaeaprocumbensRoxb. (Labiateae), VitisviniferaL. (Vitaceae) and CyperusrotundusL. (Cyperaceae). Afr J Biomed Res 9(2): 89-93.
15. Thangjam Rubee Chanu, Vasudha Pai, Rituparna Chakraborty, Bangar Raju, Richard Lobo, et al. (2011) Screening for antidiarrheal activity of Psidium guajava. A possible alternative in the treatment against diarrhea causing enteric pathogens. J Chem Pharm Res 3(6): 961-967.

16. Rabbani GH, Teka T, Zaman B, Majid N, Khatun M, et al. (2001) Clinical studies in persistent diarrhea: dietary management with green banana or pectin in Bangladeshi children. Gastroenterology 121(3): 554-560.

17. Subbotina MD, Timchenko VN, Vorobyov MM, Konunova YS Aleksandrovih YS, et al. (2003) Effect of oral administration of tormentil root extract (Potentillatormentilla) on rotavirus diarrhea in children: a randomized, double blind, controlled trial. Pediatr Infect Dis J 22(8): 706-711.

18. Vanderhoof JA, Murray ND, Paule CL, Ostrom KM (1997) Use of soy fiber in acute diarrhea in infants and toddlers. Clin Pediatr (Phila) 36(3): 135139.

19. Guerrero CA, Zarate S, Corkidi G, Lopez S, Arias CF (2000) Biochemical characterization of rotavirus receptors in MA104 cells. J Virol 74(20): 9362-9371.

20. Asha, Sivaji (2014) Euphorbia hirta linn -a review on traditional uses, phytochemistry and pharmacology. World Journal of Pharmaceutical Research 3(4): 180-205.

21. Chew AL, Jessica JJA, Sasidharan S (2012) Antioxidant and antibacterial activity of different parts ofLeucas aspera. Asian Pac J Trop Biomed 2(3): 176-180.

22. Nabil BSA, R Zyed, AL Mohamed, Souad S, Mahjoub A (2012) Assessment of the cytotoxic effect and in vitro evaluation of the anti-enteroviral activities of plants rich in flavonoids. Journal of Applied Pharmaceutical Science 2(5): 74-78.

23. Barnard DL, Hill CL, Gage T, Matheson JE, Huffman JH, et al. (1997) Potential inhibition of respiratory syncytial virus by polyoxometalates of several structural classes. AntiviralRes 34(1): 27-37.

24. Ponnambalam Arun, Kaveri Krishnasami, Palani Gunasekeran, Vidya Padmanabhan (2017) Comparative Study and Phytochemical Screening, DPPH Free Radical Scavenging and in-vitro. Study of cytotoxic activity of Andrographis paniculata and Leucas aspera on MA104. ejpmr 4(8): 643-648.

25. Alzira B Cecílio, Pollyana de C. Oliveira, Sérgio Caldas, Priscilla RV Campana, et al. (2016) Antiviral activity of Myracrodruonurundeuva against rotavirus. RevistaBrasileira de Farmacognosia 26(2): 197-202.

26. Mohamed Shaheen, Samy Mostafa, Nagwa El Esnawy (2015) In vitro and in vivo Anti-rotaviral Activity of C. alata extracts. Journal of Research in Applied Sciences 2(3): 63-71.

27. Brijesh S, Daswani P, Tetali P, Antia N, Birdi T (2009) Studies on the antidiarrhoeal activity of Aegle marmelosunripe fruit: Validating its traditional usage. BMC Complementary and Alternative Medicine 9: 47.

28. Cecílio AB, de Faria DB, Oliveira Pde C, Caldas S, de Oliveira DA, et al. (2012) Screening of Brazilian medicinal plants for antiviral activity against rotavirus. Journal of Ethnopharmacology 141(3): 975-981.

29. Luciane Anita Savi, Thiago Caon, Ana Paula de Oliveira, Andrea Michel Sobottka, Simões CM, et al. (2010) Evaluation of antirotavirus activity of flavonoids. Fitoterapia 81(8): 1142-1146.

30. Ha Hyun Kim, Hyung Jun Kwon, Young Bae Ryu, Jong Sun Chang, Kyoung Oh Cho, et al. (2012) Antiviral activity of Alpinia katsumadai extracts against rotaviruses. Res Vet Sci 92(2): 320-323.

31. Andrea Civra, Rachele Francese, Davide Sinato, Manuela Donalisio (2011) In vitro screening for antiviral activity of Turkish plants revealing methanolic extract of Rinderalanata var. lanata active against human rotavirus. BMC Complementary and Alternative Medicine 17: 74. 
(C) (i) This work is licensed under Creative

To Submit Your Article Click Here:

DOI: 10.32474 /PAPN.2019.02.000130

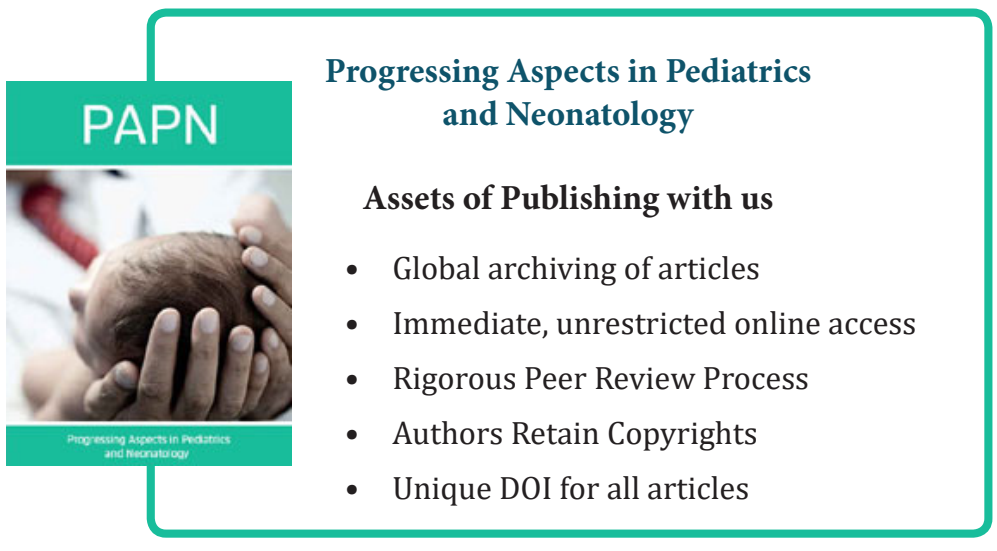

